\title{
Structure of the $\mathbf{5}^{\prime}$ region of the $\mathbf{H s t 7 0}$ gene transcription unit: presence of an intron and multiple transcription initiation sites
}

\author{
Dorota ŚCIEGLIŃSKA*, Wiesława WID̄ŁAK*, Witold KONOPKA*, Matti POUTANEN $\dagger$, Nafis RAHMAN $\dagger$, IIpo HUHTANIEMI $\dagger$ \\ and Zdzisław KRAWCZYK*1 \\ *Department of Tumor Biology, Centre of Oncology, Maria Sklodowska-Curie Memorial Institute, Wybrzeże Armii Krajowej 15, 44-100 Gliwice, Poland, and †Department \\ of Physiology, University of Turku, Kiinamyllynkatu 10, 20520 Turku, Finland
}

The rat $H s t 70$ gene and its mouse counterpart $H s p 70.2$ belong to the family of $H s p 70$ heat shock genes and are specifically expressed in male germ cells. Previous studies regarding the structure of the $5^{\prime}$ region of the transcription unit of these genes as well as localization of the 'cis' elements conferring their testisspecific expression gave contradictory results [Widłak, Markkula, Krawczyk, Kananen and Huhtaniemi (1995) Biochim. Biophys. Acta 1264, 191-200; Dix, Rosario-Herrle, Gotoh, Mori, Goulding, Barret and Eddy (1996) Dev. Biol. 174, 310-321]. In the present paper we solve these controversies and show that the $5^{\prime}$ untranslated region (UTR) of the Hst70 gene contains an intron which is localized similar to that of the mouse Hsp 70.2 gene. Reverse transcriptase-mediated PCR, Northern blotting and RNase protection analysis revealed that the transcription initiation of both genes starts at two main distant sites, and one of them is localized within the intron. As a result two populations of $H s t 70$ gene transcripts with similar sizes but different $5^{\prime}$ UTR structures can be detected in total testicular RNA. Functional analysis of the Hst70 gene promoter in transgenic mice and transient transfection assays proved that the DNA fragment of approx. $360 \mathrm{bp}$ localized upstream of the ATG transcription start codon is the minimal promoter required for testis-specific expression of the HST70/chloramphenicol acetyltransferase transgene. These experiments also suggest that the expression of the gene may depend on 'cis' regulatory elements localized within exon 1 and the intron sequences.

Key words: hsp70, spermatogenesis, testis-specific, transgenic mice.

\section{INTRODUCTION}

The multigene family of mouse and rat $\mathrm{Hsp} 70$ heat-shock or 'stress' genes includes two genes specifically expressed in spermatogenic cells. One of them, named Hsc70t in the mouse [1,2], and $H s p 70.3$ in the rat [3], is activated in round spermatids. Another one, called Hst70 in the rat [4,5], and Hsp70.2 in the mouse [6], is highly expressed in pachytene spermatocytes [6-8]. In somatic tissues, the expression level of these genes is very low and transcripts are detectable only with the most sensitive methods $[9,10]$. The HSP70.2 protein was shown to be essential for the development of male germ cells [11,12]. In Hsp70.2 $(-/-)$ mice the synaptonemal complex fails to disassemble, and primary spermatocytes arrest in meiosis I and undergo apoptosis, leading to male infertility, while the fertility of the females is unaffected [11,12]. The HSP70.2 protein is also a molecular chaperone for cyclin B-dependent kinase CDC2, whose activity is essential for the $\mathrm{G} 2 / \mathrm{M}$-phase transition during meiotic division I [13].

Molecular mechanisms regulating transcription of the $H s p 70.2 /$ $H s t 70$ genes are not yet known. Characterizing the promoter region, we showed previously that the transcription start site of the rat $H s t 70$ gene, as well as that of $H s p 70.2$, is localized 115-120 bp upstream of the ATG translation start codon [5,14]. We also performed functional studies with the Hst70 gene promoter, which showed that a $252 \mathrm{bp}$ region upstream of the transcription start site ( $367 \mathrm{bp}$ upstream of the ATG codon) is sufficient to direct expression of a chloramphenicol acetyltransferase (CAT) reporter gene with high specificity to testes of adult transgenic mice, and to activate the transgene in a developmentally regulated fashion [14].
However, in a similar study on the mouse Hsp70.2 gene promoter it was found that transcription of the gene begins as far as 353 bp upstream of the ATG codon [15]. It was also shown that the $640 \mathrm{bp}$ region upstream of the ATG codon is required for HSP70.2/LacZ transgene expression. Moreover, the 5' end of the gene was observed to contain a 239 bp-long intron, that is spliced out of the pre-mRNA transcript leaving a 108 nt-long untranslated exon 1 in the mature mRNA molecule [15]. Taking into account the considerable similarities of the nucleotide sequences and expression patterns between the Hst70 and Hsp70.2 genes $[2,5,8,14,15]$, such controversy concerning localization of the transcription initiation site became a serious drawback affecting the search for the 'cis' and 'trans' regulatory elements.

In the present study we have solved these controversies by demonstrating that the transcription of the Hst70 gene could be initiated from two main sites. We also provide evidence for the existence of an intron in the $5^{\prime}$ untranslated region (UTR) of the $H s t 70$ gene, and show that in total testicular RNA two Hst70 gene transcripts, each with different 5' UTRs, can be detected. We took advantage of creating transgenic mice for in vivo functional studies and in vitro transient transfection assays to determine the most probable localization of the regulatory region of the Hst70 gene.

\section{MATERIALS AND METHODS}

\section{Isolation of RNA and DNA}

Total RNA was prepared from the testes of Wistar rats and C57BL/6 mice using the guanidinium isothiocyanate method [16]. RNA samples were purified from DNA contaminations, as

Abbreviations used: CAT, chloramphenicol acetyltransferase; poly $(A)^{+}$, polyadenylated; RT-PCR, reverse transcriptase-mediated PCR; UTR, untranslated region.

1 To whom correspondence should be addressed (e-mail krawczyk@io.gliwice.pl). 
Table 1 PCR primers for the Hst70 gene

Product length (nt)

\begin{tabular}{|c|c|c|c|c|c|}
\hline Upper primer (sequence) & Position in Hst70 gene* & Lower primer (sequence) & Position in Hst70 gene* & PCR & RT-PCR \\
\hline Ex1a (5'-GGCTTCATTTGCATAACGGCCGCCCCTTGG-3') & -322 to -351 & Ex2b (5'-AGTAAGTGGTGCCCAGGTCGATGCCGATAG-3') & +20 to +49 & 400 & 161 \\
\hline Ex1b (5'-GAGTCCCGCTCTCACCCACCTAG-3') & -281 to -303 & Ex2b (5'-AGTAAGTGGTGCCCAGGTCGATGCCGATAG-3') & +20 to +49 & 352 & 113 \\
\hline Ex1a (5'-GGCTTCATTTGCATAACGGCCGCCCCTTGG-3') & -322 to -351 & Ex2a (5'-GGTCGATGCCGATAGCCGGG-3') & +15 to +34 & 384 & 145 \\
\hline Int2 (5'-CGCTCGTGGAGAGCAGTGCGA-3') & -80 to -100 & Ex2b (5'-AGTAAGTGGTGCCCAGGTCGATGCCGATAG-3') & +20 to +49 & 149 & 149 \\
\hline Int1 (5'-ACGACTATAAGACGGAGAAG-3') & -131 to -150 & Ex2b (5'-AGTAAGTGGTGCCCAGGTCGATGCCGATAG-3') & +20 to +49 & 199 & 199 \\
\hline
\end{tabular}

* The GenBank ${ }^{\circledR}$ rat Hst70 gene accession number is X15705.

Table 2 Oligonucleotide probes used in Northern hybridization

\begin{tabular}{|c|c|c|c|}
\hline Target gene & Oligo & Sequence & Position in gene (nt) \\
\hline \multirow[t]{4}{*}{ Rat $H s t 70^{\star}$} & rP1 & 5'-AGGTGGGTGAGAGCGGGACTCCAGC-3' & -283 to -307 \\
\hline & $\mathrm{rPi}$ & 5'-CCGTCCAACCCGTCCAGCGATC-3' & -210 to -232 \\
\hline & $\mathrm{rP2} 2$ & 5'-GGTCGCTTCGCACTGCTCTCCAC-3' & -73 to -95 \\
\hline & $\mathrm{rP} 1 / 2$ & 5'-GTTTACGCGGACTCCAGCGCAAGC-3' & +1843 to +1866 \\
\hline \multirow{4}{*}{ Mouse Hsp70.2† } & $\mathrm{mP1}$ & 5'-TTGGGTGAGGCGCTTGACGCCA-3' & -285 to -306 \\
\hline & $\mathrm{mPi}$ & 5'-GCTCCAACCCGTCCGGCGCTC-3' & -212 to -232 \\
\hline & mP2 & 5'-CGGTCGCTTCTCACAACTCTCCACGAG-3' & -79 to -105 \\
\hline & $\mathrm{mP} 1 / 2$ & 5'-GTTTACGCGGACTCCAGCGCAAGC-3' & +1912 to + 1946 \\
\hline
\end{tabular}

* GenBank ${ }^{\mathbb{R}}$ accession number X15705.

† GeneBank ${ }^{\mathbb{R}}$ accession number M20567.

described previously [10]. In brief, RNA was treated with RNasefree DNase I RQ1 (Promega). Then, aliquots of DNase Idigested samples were additionally treated with RNase A and were used for control reverse transcriptase-mediated PCR (RT$\mathrm{PCR})$ reactions. Polyadenylated $\left[\operatorname{poly}(\mathrm{A})^{+}\right] \mathrm{RNA}$ was isolated through two cycles of oligo(dT)-cellulose (Boehringer) chromatography. DNA was isolated from the livers of Wistar rats and C57BL/6 mice as described in [17].

\section{RT-PCR and PCR}

RT-PCR assays were performed as described previously [10]. At the reverse transcription step the reaction mixture (final volume of $50 \mu \mathrm{l}$ ) contained PCR reaction buffer (Qiagen), $0.2 \mathrm{mM}$ each $\mathrm{dNTP}, 0.4 \mu \mathrm{M}$ lower primer (see Table 1 ), $1 \mu \mathrm{g}$ of RNA, 50 units of Moloney-murine-leukaemia virus reverse transcriptase (Gibco BRL) and 2 units of Taq polymerase (Qiagen). Samples were incubated in a thermal cycler (PerkinElmer; type 3200) for $10 \mathrm{~min}$ at $50{ }^{\circ} \mathrm{C}$. Immediately after addition of $0.4 \mu \mathrm{M}$ upper primer (Table 1) 35 cycles of the PCR reaction were performed $\left(94{ }^{\circ} \mathrm{C}\right.$ for $30 \mathrm{~s}, 55-65^{\circ} \mathrm{C}$ for $30 \mathrm{~s}$, and $72{ }^{\circ} \mathrm{C}$ for $\left.45 \mathrm{~s}\right)$. RTPCR products were analysed on a $2 \%(\mathrm{w} / \mathrm{v})$ agarose gel containing ethidium bromide. In order to determine the length of an intron and the localization of splicing sites RT-PCR products were purified with a QIAEX gel extraction kit (Qiagen) and sequenced using a ThermoSequenase dye terminator cycle sequencing pre-mix kit (Amersham). The reaction products were analysed using a ABI377 DNA Sequencer (PerkinElmer). Sequences of primers used in the PCR and RT-PCR reactions, as well as the length of the products, are summarized in Table 1.

\section{Northern blots}

Total RNA isolated from rat and mice testes was fractionated on $1.2 \%(\mathrm{w} / \mathrm{v})$ agarose $/ 2.2 \mathrm{M}$ formaldehyde gels (20 $\mu \mathrm{g}$ per lane). Following electrophoresis the RNA was transferred on to
Hybond- $\mathrm{N}^{+}$membranes (Amersham) by capillary blotting. Hybridization mixture contained $5 \times$ SSC (where $1 \times$ SSC corresponds to $0.15 \mathrm{M} \mathrm{NaCl} / 0.015 \mathrm{M}$ sodium citrate), $0.5 \% \mathrm{SDS}$, $5 \times$ Denhardt's solution (where $1 \times$ Denhardt's solution corresponds to $0.02 \%$ Ficoll $400 / 0.02 \%$ polyvinylpyrrolidone/ $0.02 \%$ BSA), $100 \mu \mathrm{g} / \mathrm{ml}$ denatured salmon sperm DNA and $20 \mathrm{pM}$ oligonucleotide probe (Table 2) $5^{\prime}$ labelled with $[\gamma-$ $\left.{ }^{32} \mathrm{P}\right] \mathrm{dATP}$ and T4 polynucleotide kinase (Boehringer). Hybridization was performed overnight at $58^{\circ} \mathrm{C}$. Blots were then washed in solution containing $5 \times \mathrm{SSC}$ and $0.1 \%$ SDS $[15 \mathrm{~min}$ at room temperature $\left(21-23{ }^{\circ} \mathrm{C}\right)$ and $20 \mathrm{~min}$ at $\left.58{ }^{\circ} \mathrm{C}\right]$ and finally exposed to X-ray film for 1-2 weeks.

\section{RNase protection assay}

RNase protection assays were performed essentially as described by Widłak et al. [14]. Poly(A) ${ }^{+}$RNA from rat testes was hybridized overnight at $45-55^{\circ} \mathrm{C}$ in $30 \mu \mathrm{l}$ of buffer [ $40 \mathrm{mM}$ Pipes (pH 6.4), $400 \mathrm{mM} \mathrm{NaCl}, 1 \mathrm{mM}$ EDTA and $80 \%(\mathrm{v} / \mathrm{v})$ formamide] with $(1-5) \times 10^{5}$ c.p.m. of the RNA probes prepared using reagents from a riboprobe kit (Promega). Hybridization products were then digested for $1 \mathrm{~h}$ at $37^{\circ} \mathrm{C}$ with $80 \mu \mathrm{g} / \mathrm{ml}$ RNase A and $4 \mu \mathrm{g} / \mathrm{ml} \mathrm{RNase} \mathrm{T1} \mathrm{in} 400 \mu \mathrm{l}$ of RNase digestion buffer [10 mM Tris/HCl (pH 7.5), $5 \mathrm{mM}$ EDTA and $300 \mathrm{mM}$ $\mathrm{NaCl}$, and after addition of SDS (final concentration of $0.5 \%$ ) they were incubated with $50 \mu \mathrm{g}$ of proteinase $\mathrm{K}(15 \mathrm{~min}$ at $\left.37^{\circ} \mathrm{C}\right)$. Products were extracted, loaded on to a $6 \%(\mathrm{w} / \mathrm{v})$ polyacrylamide $/ 7 \mathrm{M}$ urea gel together with size markers [DNA restriction fragments generated from a pBluescript SK $(+)$ vector digested with $M s p \mathrm{I}]$ end-labelled with $\left[\gamma_{-}{ }^{32} \mathrm{P}\right] \mathrm{dATP}$ and T4 polynucleotide kinase (Boehringer), and visualized by autoradiography for up to 2 weeks. The template used to generate riboprobes was a plasmid containing a HincII-DraII fragment (nucleotides -458 to -62 ) of the Hst70 gene inserted into the pBluescript SK(+) vector (for construction details see [14]). 
Plasmid was linearized with either the EcoRV restriction enzyme to obtain the 'short' probe or EcoRI to obtain the 'long' probe. The RNA probe was synthesized from the T7 promoter.

\section{Recombinant plasmids}

The recombinant plasmids used for microinjection were constructed by inserting different fragments (described below) of the $5^{\prime}$ flanking region of the rat $H s t 70$ gene in front of the promoterless CAT gene cloned into the pBLCAT6 plasmid as described previously [14]. In the pHST(326/D)CAT plasmid the CAT gene was ligated with the StyI $(-326)-\operatorname{DraII}(-62)$ fragment, and in the pHST(278/D)CAT plasmid the CAT gene was ligated with the EcoRV(-278)-DraII( - 62) fragment (see Figure 4B). Numbers refer to the position of A (assigned as +1 ) in the ATG codon of the $H s t 70$ gene. For a transient transfection assay the following plasmids containing 3 '-end truncated fragments of the Hst70 gene promoter region were constructed: pHST(H/D)CAT, pHST(H/B)CAT, pHST(H/EV)CAT and pHST $(\mathrm{H} / \mathrm{Bs}) \mathrm{CAT}$. These plasmids were constructed by inserting into the multiple-cloning-site region of the pBLCAT6 vector the following restriction fragments: $\operatorname{HindIII}(-896)-\operatorname{DraII}(-62)$, HindIII $(-896)-B a m H I(-120)$, HindIII $(-896)-E c o$ RV $(-278)$ and HindIII $(-896)-B s t \mathrm{XI}(-367)$ respectively (see Figure 5B). Details of the cloning procedure are available on request.

\section{Generation of transgenic mice}

Transgenic mice were essentially obtained as described previously $[14,18]$. Constructs used for microinjection were digested with HindIII and KpnI. Appropriate restriction fragments were recovered from agarose gels with GFX PCR DNA and a Gel Band Purification Kit (Amersham Pharmacia Biotech), and then purified with Elutip-d (Schleicher and Schuell), precipitated with ethanol and diluted to $1-5 \mathrm{ng} / \mu \mathrm{l}$ in $10 \mathrm{mM}$ Tris $/ \mathrm{HCl}$ $(\mathrm{pH} 7.4) / 0.1 \mathrm{mM}$ EDTA for microinjection. The DNA was microinjected into the pronuclei of zygotes from $\mathrm{FVB} / \mathrm{N}$ females. Transgenic founders were screened by PCR using CAT and $H s t 70$ specific primers and DNA isolated from tail biopsies [14].

\section{Cell culture and transient transfections}

Rat hepatoma cell line FTO-2B was grown in Dulbecco's modified Eagle's medium/Ham's medium (1:1, v/v; Gibco BRL) supplemented with $10 \%(\mathrm{v} / \mathrm{v})$ fetal calf serum (Gibco BRL). Cells were transfected by electroporation essentially as described previously [19], using a Bio-Rad Gene Pulser in combination with a Bio-Rad capacitance extender $(260 \mathrm{~V}$ and $950 \mu \mathrm{F}$ ). Following electroporation, cells were grown at $37^{\circ} \mathrm{C}$ for $48 \mathrm{~h}$ before harvesting and then the CAT assay was performed as described below.

\section{Isolation of tissue and cell extracts, and the CAT assay}

Tissue homogenates were prepared as described previously $[14,20]$. In brief, excised tissues were frozen in liquid nitrogen and then homogenized in 5-10 vol. of solution A $[0.15 \mathrm{M}$ Tris $/ \mathrm{HCl}$ (pH 8.0), $60 \mathrm{mM} \mathrm{KCl}, 15 \mathrm{mM} \mathrm{NaCl}, 2 \mathrm{mM}$ EDTA, $0.15 \mathrm{mM}$ spermine, $1 \mathrm{mM}$ dithiothreitol and $0.4 \mathrm{mM}$ PMSF]. Cell extracts were prepared by the Tris buffer freeze-thaw protocol. To perform the CAT assay, $100 \mu \mathrm{l}$ of cell or tissue extract was added to $100 \mu \mathrm{l}$ of the reaction mixture containing $0.25 \mathrm{M}$ Tris $/ \mathrm{HCl}$ (pH 7.8), 1 mM EDTA, $4 \mu \mathrm{l}$ of $100 \mathrm{mM}$ acetyl-CoA (Sigma) and $2.5 \mu \mathrm{l}$ of $\left[{ }^{14} \mathrm{C}\right]$ chloramphenicol $(2.5 \mu \mathrm{Ci} / \mathrm{ml}$; Amersham $)$. In the case of cell extracts, the CAT assay mixture contained $10 \mu \mathrm{g}$ of protein and samples were incubated for $2 \mathrm{~h}$ at $37^{\circ} \mathrm{C}$. In the case of tissue extracts, the CAT assay mixture contained $200 \mu \mathrm{g}$ of protein and samples were incubated for $4-5 \mathrm{~h}$ at $37^{\circ} \mathrm{C}$. The acetylated forms of chloramphenicol were separated by TLC as described previously [14]. Total protein content of the supernatant was determined after heating extracts to $65^{\circ} \mathrm{C}$ for $10 \mathrm{~min}$ [21].

\section{RESULTS}

\section{Structure of the $\mathbf{H s t 7 0}$ gene $\mathbf{5}^{\prime}$-flanking region}

To determine the structure of the $5^{\prime}$ region of the $H s t 70$ gene we assumed that the general structures of the transcription units of both homologous genes, i.e. the mouse $H s p 70.2$ gene and the rat $H s t 70$ gene, are similar. We found such an assumption justified by the fact that both genes share high nucleotide sequence similarity, not only within the coding region but also upstream of the ATG codon $[5,15]$. The presumed structure of the $5^{\prime}$ end of the Hst70 gene is shown schematically in Figure 1(A). The indicated transcription initiation sites $\mathrm{T} 1$ and $\mathrm{T} 2$ correspond to the position determined by Dix et al. [15] for the Hsp70.2 gene (T1) and to the position determined by us (T2), which we found to be the same in $H s t 70$ and Hsp70.2 genes [5,14].

Searches for a possible intron at the $5^{\prime}$ end of the Hst70 gene as well as the existence of transcripts originating from distinct transcription start sites of the gene were performed using RTPCR and PCR with several sets of primers, as listed in Table 1. Figure 1(B) shows that the RT-PCR products amplified with primers complementary to sequences of putative exons 1 and 2 were approx. $200 \mathrm{bp}$ shorter than the PCR fragments amplified from the genomic DNA (for details about differences in product lengths see Table 1). This result reveals the presence of an intron separating exons 1 and 2 at the $5^{\prime}$ end of the Hst70 gene. The exon splice sites and the length of the intron (239 bp) were determined by sequencing RT-PCR products and were confirmed to correspond to those found in the mouse gene ([15], and results not shown).

When PCR and RT-PCR analyses were performed with primers complementary to sequences within the intron, either downstream or upstream of the transcription start site T2 and exon 2 respectively, the length of the RT-PCR amplicons was always the same as the PCR fragment obtained from the total DNA template (Figure 1C). These data indicate that these transcripts were, in fact, initiated within the intron of the Hst70 gene.

To further characterize the $H s t 70$ and $H s p 70.2$ gene transcripts originating from different initiation sites, we performed Northern-blot analysis. Total RNA from rat and mouse testes was fractionated on agarose/formaldehyde gels, and Northern blots were hybridized to ${ }^{32} \mathrm{P}$-labelled oligonucleotide probes specific for various regions of the Hst70 and the Hsp70.2 genes (for detailed sequences and the position of these probes see Table 2 and the legend to Figure 2). Northern-blot analysis revealed complex but similar hybridization patterns for both the $\mathrm{Hst} 70$ and the Hsp70.2 gene transcripts. Probes $\mathrm{P} 1$ and $\mathrm{P} 1 / 2$, specific for exon 1 and for the 3' UTR respectively, hybridized most effectively. Probe P2, complementary to intron sequences and localized downstream of the T2 transcription start site, also gave a hybridization signal, but much weaker than that with the P1 and $\mathrm{P} 1 / 2$ probes. In contrast, no $H s t 70 / H s p 70.2$ gene-specific signal was observed with probe $\mathrm{Pi}$, specific for intron sequences localized far upstream of the T2 transcription site.

These data show that the transcripts detected by probe P1 were initiated at around $\mathrm{T} 1$ and that the transcripts detected by the probe P2 were initiated at around T2. Lack of a Hst70/Hsp70.2specific band when the $\mathrm{Pi}$ probes were used for hybridization 
A

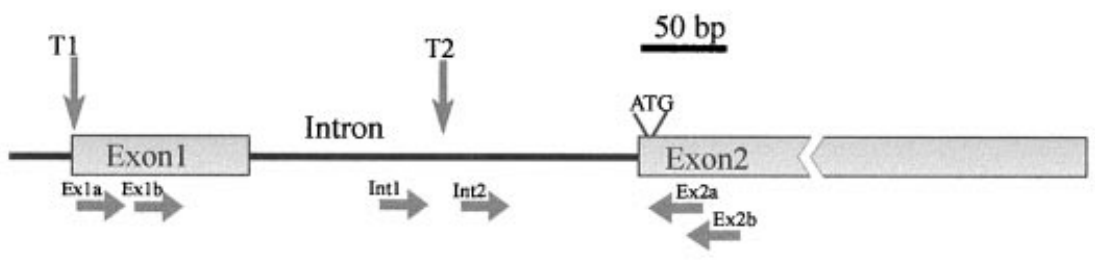

B
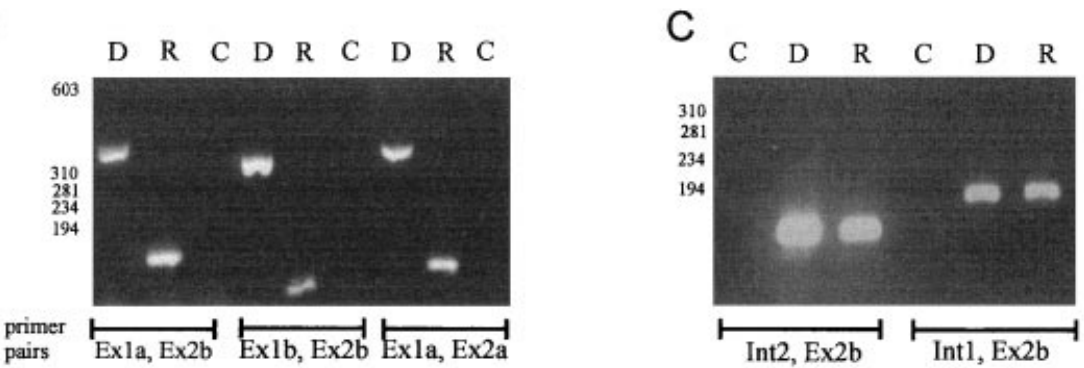

\section{Figure 1 Detection of two main Hst70 gene transcripts in rat testicular RNA}

(A) A scheme showing the presumed structure of the $5^{\prime}$ part of the Hst70 gene. Vertical arrows indicate the postulated positions of two main transcription start sites marked T1 and T2. Horizontal arrows represent the oligonucleotide primers used in the RT-PCR and PCR reactions (for nucleotide sequences and positions of the primers see Table 1). (B) RT-PCR analysis revealing the presence of an intron in the $5^{\prime}$ part of the gene. D, Products of PCR reactions with genomic DNA as a template; R, products of RT-PCR reactions with total testicular RNA as a template; $C$, control RTPCR reactions with RNA digested with DNase I and RNase A (for details see the Materials and methods section). (C) RT-PCR analysis showing transcripts of the Hst70 gene initiated within the intron. Numbers on the left-hand side of each photograph indicate the sizes (in bp) of DNA markers. The primer pairs used in the reactions are described under each photograph.

(cross-hybridization of the probe to ribosomal RNA can only be seen) shows that the intron sequences were spliced out from the transcripts initiated around T1. Thus the final pool of the Hst70 and the Hsp70.2 gene transcripts consists of different populations of molecules initiated predominantly at or around T1 and T2 transcription sites. It has to be noted that the transcripts initiated from the two main initiation sites $\mathrm{T} 1$ and $\mathrm{T} 2$ have identical coding and 3' UTR regions but differ in their 5' UTR sequences. They also have a very similar size (their $5^{\prime}$ UTR length differs by only 4 nucleotides). Thus these transcripts cannot be recognized by size fractionation on agarose gels.

The data presented so far confirmed the structure of the transcription unit of the Hst70 gene as shown in Figure 1(A). Existence of multiple initiation sites of the Hst70 gene was further analysed using the RNase protection assay. Two specific RNA probes were prepared on templates derived from DNA sequences from the ATG upstream region of the Hst70 gene (Figure 3A). The 'long' probe (430 bp), synthesized from a HincII-DraII fragment (nucleotides -458 to -62 ) cloned into pBluescript SK $(+)$, was complementary to the 5 -end sequences possibly present in transcripts originating from sites $\mathrm{T} 1$ and $\mathrm{T} 2$. The 'short' probe $(250 \mathrm{bp})$, synthesized from an EcoRV-DraII fragment (nucleotides -278 to -62 ) cloned into pBluescript SK $(+)$, was complementary to $5^{\prime}$-end sequences possibly present in transcripts originating only around site $\mathrm{T} 2$ (Figure $3 \mathrm{~A}$ ). These probes were hybridized with testicular poly $(\mathrm{A})^{+}$RNA and the results of the RNase protection assay are presented in Figures 3(B) and 3(C).

As was expected, the two probes protected a different set of fragments with only one 57 nt-long common band. As was shown previously, this band corresponds to transcripts originating from the T2 site [14]. The longer probe, besides the already mentioned $57 \mathrm{nt}$-long fragment, also protected several longer fragments with the most distinct ones being approx. 105 and $95 \mathrm{nt}$ (Figure 3B). The sizes of these bands correspond to the predicted protected products matching with transcripts initiated at sites equivalent to the ones mapped by Dix et al. [15]. As expected, these fragments were absent from the set protected by the shorter probe (Figure 3C). Instead, the shorter probe, besides the common $57 \mathrm{nt}$-long fragment, also protected a shorter fragment of approx. $34 \mathrm{nt}$. The probable origin of all main protected fragments is explained in Figure 3(A). Other lowintensity bands visible in the gel most probably reflect transcription from minor sites positioned between the two main ones localized at approx. $353 \mathrm{nt}$ and $116 \mathrm{nt}$ upstream of the ATG codon.

\section{Functional studies of the $\mathrm{Hst70}$ gene promoter}

In a previous paper we showed that a BstXI (-367)-DraII $(-62)$ fragment of the $H s t 70$ promoter ( $252 \mathrm{bp}$ upstream of the T2 site) was sufficient to promote testis-specific expression of the HST70/ CAT transgene (transgenic line 252/D, [14]). To further determine the minimal size required for the $H s t 70$ gene promoter to be active in testes, we obtained transgenic mice bearing shorter fragments of the Hst70 gene promoter. Transgenes named pHST(326/D)CAT and pHST(278/D)CAT were constructed by ligating the StyI $(-326)-\operatorname{DraII}(-62)$ fragment and the EcoRV (-278)-DraII (-62) fragment, respectively, to the CAT reporter gene (Figure 4A).

Established lines of transgenic mice bearing the pHST(326/ D)CAT and the pHST(278/D)CAT hybrid genes are abbreviated as $326 / \mathrm{D}$ and $278 / \mathrm{D}$ respectively. The numbers of established transgenic lines were six for 326/D and one for 278/D. As a positive reference we used a previously described transgenic mice line 252/D [14] bearing the hybrid gene called pHST(367/D)CAT 


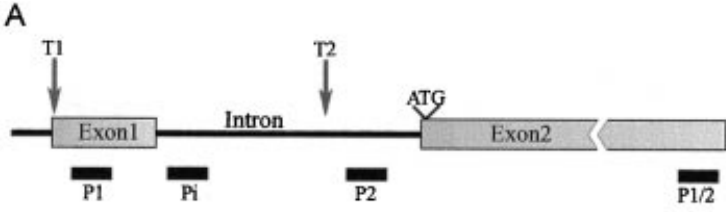

B

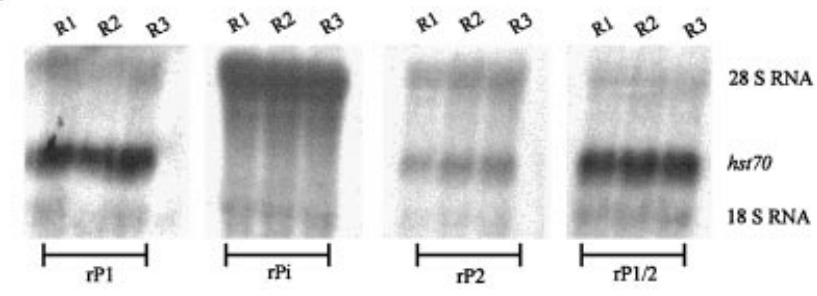

C

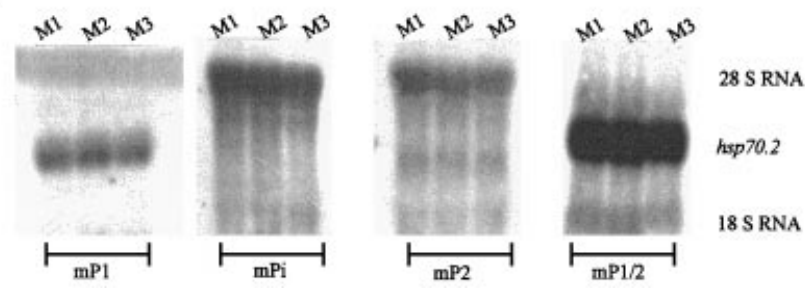

Figure 2 Northern-blot analysis of the rat Hst70 gene and the mouse Hsp70.2 gene transcripts

(A) Schematic structure of the $5^{\prime}$ part of the $H s t 70 / H s p 70.2$ genes. Vertical arrows indicate the positions of the main transcription start sites. Black bars represent oligonucleotide probes (details of the nucleotide sequences and positions of probes are summarized in Table 2). (B) Hybridization of total rat testicular RNA with the following probes: rP1, specific for exon 1; rPi, specific for the intron; rP2, specific for the $5^{\prime}$ UTR of transcripts initiated at the T2 transcription start site; and rP1/2, specific for the $3^{\prime}$ UTR part of the Hst70 gene. R1-R3 indicate RNA samples from three different rats. Each lane was loaded with $20 \mu \mathrm{g}$ of RNA. (C) Hybridization of total mouse testicular RNA with the following probes: $\mathrm{mP1}$, specific for exon 1 ; $\mathrm{mPi}$, specific for the intron; mP2, specific for the $5^{\prime}$ UTR of transcripts initiated at the T2 transcription start site; and $\mathrm{mP1} / 2$, specific for the $3^{\prime}$ UTR part of the Hsp70.2 gene. M1-M3 indicate RNA samples isolated from three different mice. Each lane was loaded with $20 \mu \mathrm{g}$ of RNA. Crosshybridization of the probes to ribosomal RNA constitutes an internal standard of RNA loading and transfer uniformity.

in this paper (see Figure 4B). Consequently, the transgenic line formerly called 252/D is called 367/D in the present paper.

The CAT activity in testes of transgenic mice lines 326/D and 278/D was at the background level (Figure 4C). Only in one out of six founders of the 326/D line was a very low level of CAT activity detected [less then $5 \%$ of that observed for mice bearing the pHST(367/D)CAT construct]. We believe that such insignificant activity of the one out of six 326/D transgenic lines can be ascribed to an integration position effect. These results show that, in fact, the minimal promoter is located within $367 \mathrm{bp}$ upstream of the ATG codon (Figures 4B and 4C).

There are reports showing that in the case of certain testisspecific genes, promoter-directed transcription can take place in transiently transfected cultured cells other than spermatogenic or testicular tissue $[19,22,23]$. In a previous paper we showed that the construct containing the CAT reporter gene linked to fragments of the $H s t 70$ gene promoter was expressed in human breast cancer and rat hepatoma cells [19]. We took advantage of this observation to determine the transcription-promoting activity of DNA subfragments obtained by the 3'-end truncation of the HindIII (-896)-DraII(-62) fragment flanking the $5^{\prime}$ end of the Hst70 gene (Figures 5A and 5B; numbers in parentheses
A
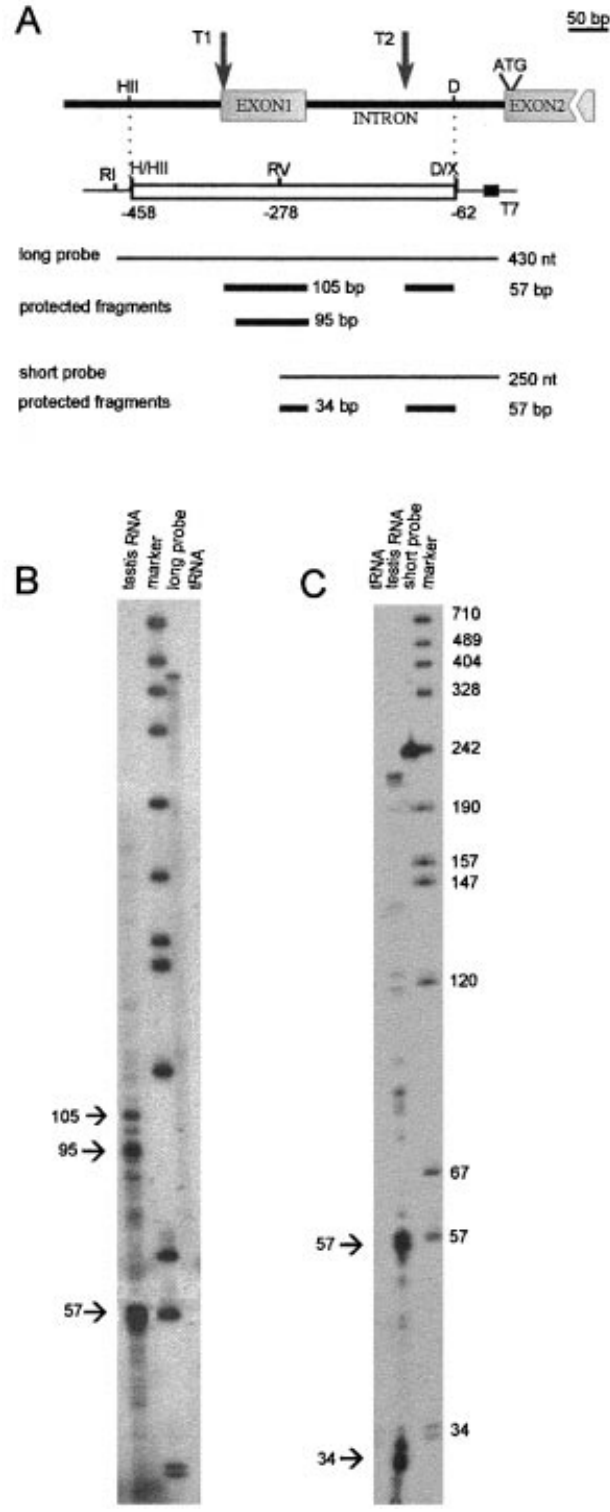

Figure 3 Analysis of the $\mathrm{Hst70}$ gene transcripts by an RNase protection assay

(A) The top part of the Figure shows the structure of the $5^{\prime}$ fragment of the $H s t 70$ gene. T1 and T2 indicate the two main transcription start sites. Below is shown a structure of a template constructed for generating specific riboprobes; the size of the probes and the expected sizes of the protected fragments are indicated. The open box indicates the Hincll-Drall restriction fragment of the $\mathrm{Hst70}$ gene cloned into the Hindlll and Xhol sites in the polylinker region of the pBluescript $\mathrm{SK}(+)$ vector. Ligation sites are marked $\mathrm{H} / \mathrm{HII}$ and $\mathrm{D} / \mathrm{X}$ respectively. Details about the plasmid construction are available on request. RV indicates a restriction site for EcoRV; digestion of the template at this restriction site results in the production of the 'short' RNA probe. RI indicates a restriction site for $E C O R I$; digestion of the template at this restriction site results in the production of the 'long' RNA probe. Thin lines are vector sequences, and the black square represents the promoter for T7 RNA polymerase. (B) Autoradiogram of a gel containing products of rat testes poly $(\mathrm{A})^{+}$RNA protection analysis using the 'long' probe. Arrows indicate the most pronounced protected fragments. (C) Autoradiogram of a gel containing products of rat testes poly $(A)^{+}$RNA protection analysis using the 'short' probe. Arrows indicate the most pronounced protected fragments. Details of the assay are described in the Materials and methods section.

indicate the position of a restriction site in relation to +1 of the ATG codon). The pHST(H/D)CAT construct containing the T1 and $\mathrm{T} 2$ sites, as well as the $\operatorname{pHST}(\mathrm{H} / \mathrm{B}) \mathrm{CAT}$ construct from 
A
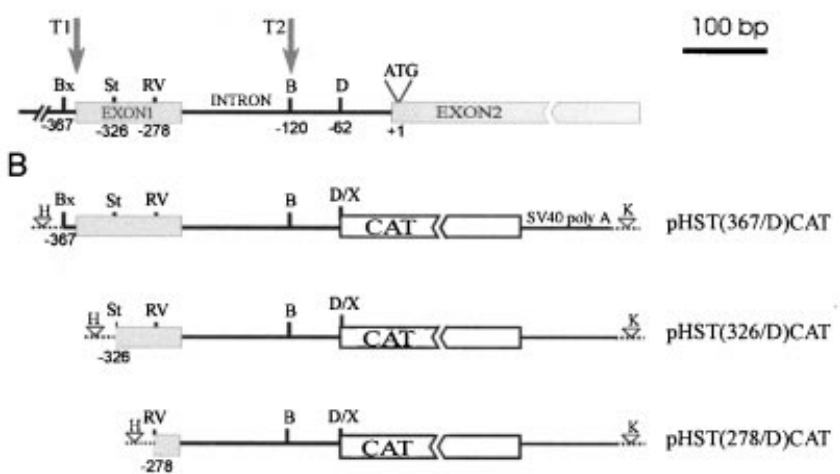

C

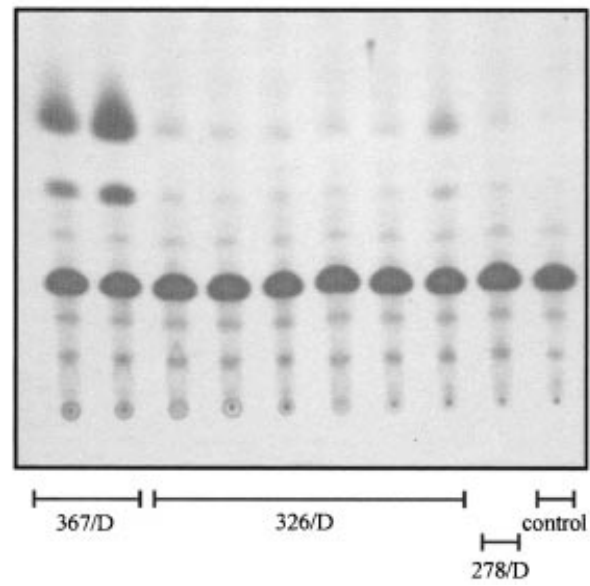

Figure 4 Functional analysis of the Hst70 promoter in transgenic mice

(A) Structure of the $5^{\prime}$ part of the $\mathrm{Hst70}$ gene. Vertical arrows show the two main transcription start sites. Bx, St, RV, B, D indicate restriction sites for BstXI, Styl, EcoRV, BamHI and Drall restriction enzymes respectively. Numbers under restriction sites are co-ordinates of the nucleotide sequence with respect to the nucleotide +1 (A in the ATG translation initiation codon). (B) Structure of the pHST70-CAT hybrid genes. The open interrupted box represents the CAT reporter gene. The thick line connected to the grey box represent the intron and exon 1 sequences respectively. Bx, St, RV, B, H, K indicate restriction sites for BstXI, Styl, EcoRV, BamHI, Hindlll and Kpnl restriction enzymes respectively. D/X is the ligation site at Drall and Xhol (both Klenow-filled). Details of the construction of the expression vectors are available on request, see also [14]. Open triangles indicate the polylinker restriction sites (HindllI at the $5^{\prime}$ end and KpnI at the $3^{\prime}$ end) used to cut off the hybrid gene for microinjection. SV40 poly A, simian virus 40 polyadenylation sequence. (C) The pattern of CAT activity in testes of 367/D, 326/D and 278/D transgenic mice. In the case of the 367/D line CAT activity was tested in mice derived from two different founders, in the case of the 326/D line CAT activity was tested in mice derived from six different founders, and in the case of the 278/D line CAT activity was tested in mice derived from one founder. Each reaction mixture contained $200 \mu \mathrm{g}$ of protein and the reaction time was $4 \mathrm{~h}$ (details are described in the Materials and methods section).

which the T2 site was removed, was efficiently transcribed. In contrast, the $\mathrm{pHST}(\mathrm{H} / \mathrm{EV}) \mathrm{CAT}$ construct which contained only the T1 region and part of exon 1, as well as the pHST(H/Bs)CAT construct from which the $\mathrm{T} 2$ region was deleted, turned out to be inactive. This result suggests that the sequences localized downstream of the T1 region (within exon 1 and the intron) are necessary for $H s t 70$ gene expression from both transcription start regions (Figure 5).

\section{DISCUSSION}

The data presented in the current paper allow us to solve the controversies regarding the structure of the $5^{\prime}$ end of the mouse
A

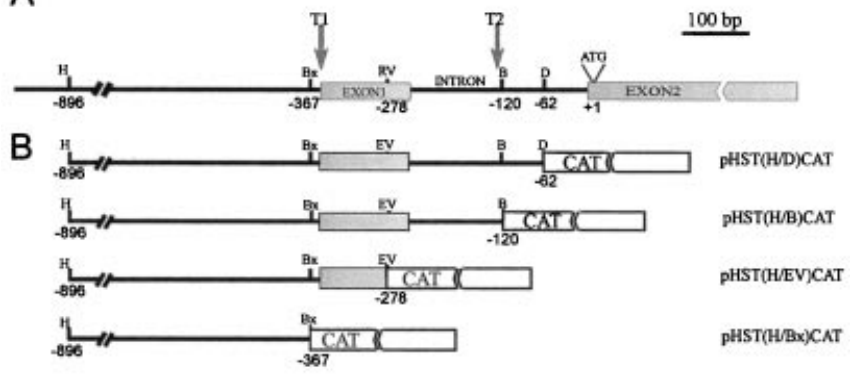

C

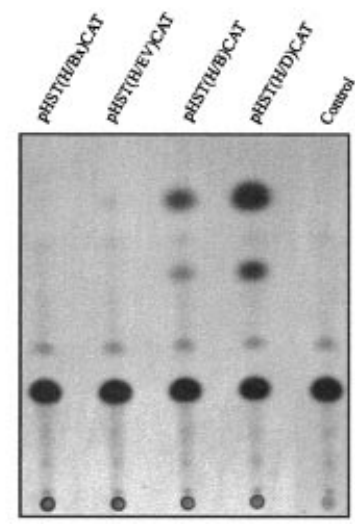

Figure 5 In vitro assay of the promoter activity of the $H s t 70$ gene-flanking DNA sequences

(A) Schematic structure of the Hst70 gene. (B) Structure of the pHST-CAT constructs used in the transfection assay. Negative numbers represent the nucleotide positions relative to the Hst70 gene ATG codon $(+1)$. Abbreviations of restriction enzymes are exactly as in the legend to Figure 4. (C) FTO-2B cells were transfected by electroporation with the plasmids described above. The CAT assay was performed with $10 \mu \mathrm{g}$ of protein, and the reaction time was $2 \mathrm{~h}$. Details are in the Materials and methods section.

and rat spermatocyte-specific $H s p 70$-related gene, indicating that the $H s t 70$ and the $H s p 70.2$ genes have similar structures. Both genes have two main distant transcription start regions, T1 and T2, localized approx. $350 \mathrm{bp}$ and $116 \mathrm{bp}$ upstream of the ATG codon respectively. In addition to the two main regions, there are multiple minor sites localized downstream of the $\mathrm{T} 1$ region and upstream of the T2 region. This heterogeneity of the initiation region seriously hampered precise determination of the $5^{\prime}$ end of the transcription unit of these genes using primer extension or RNase protection methods ([14,15,24], and the present paper). Therefore we suggest referring to two initiation regions, T1 and $\mathrm{T} 2$, instead of strictly defined initiation sites.

Transcription of the Hst70 and the Hsp70.2 genes from the T1 region gives transcripts from which the $239 \mathrm{bp}$-long intronic sequences are spliced out in both the mouse and rat ([15], and the present paper). In contrast, transcription from the $\mathrm{T} 2$ region, which is localized within an intron, gives non-spliced mRNA molecules. Thus the transcription of the Hst70 gene and the $H_{s p} 70.2$ gene generates two main populations of mRNA molecules with similar sizes but different $5^{\prime}$ UTR sequences (112 and $116 \mathrm{bp}$ in the case of transcripts initiated in the T1 and T2 regions respectively). These different populations coexist and can be recognized only by hybridization with probes specific to different $5^{\prime}$-end UTR sequences.

So far, we have not been able to propose any explanation for the presence of two transcription regions in these genes. They 
A
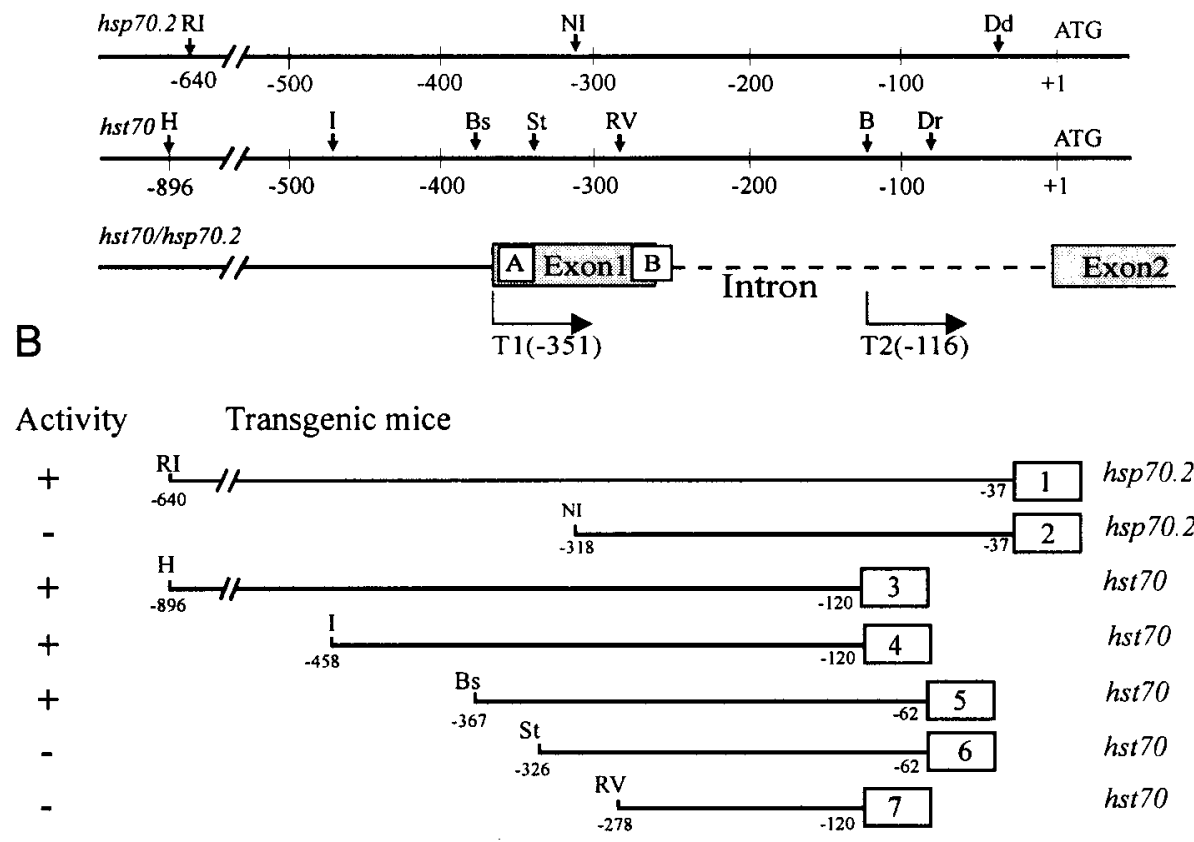

Transient transfection

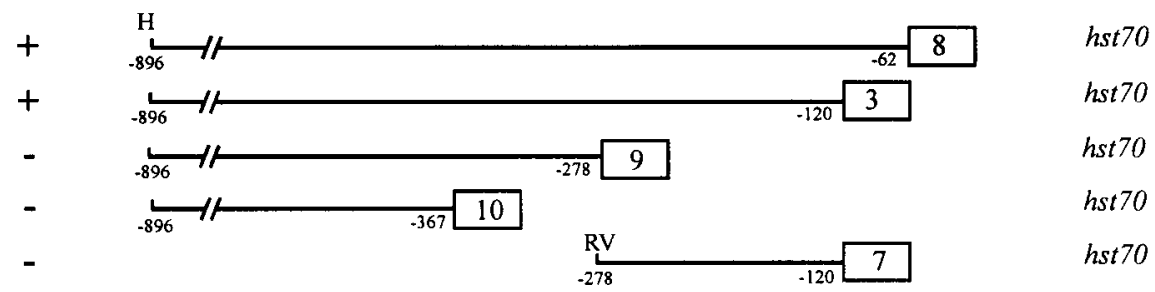

Figure 6 Compilation of data on the functional analysis of the $H s t 70$ and $H s p 70.2$ gene promoters

(A) The bottom part shows a schematic structure of the rat Hst70 and the mouse Hsp70.2 genes in the region upstream of the ATG codon. Similarity in the nucleotide sequence, internal order and exon 1/exon 2 splicing sites between both genes justifies drawing this part of the Hsp70.2 and Hst70 genes as having a common structure. Intron length in the case of both the rat and the mouse gene is $239 \mathrm{bp}$. Boxes A and B represent the regions of the highest similarity between the promoters of the rat Hst70 gene ([5]; GenBank ${ }^{\mathbb{R}}$ accession number X15705), the mouse Hsp70.2 gene ([6]; GenBank ${ }^{\circledR}$ accession number M20567) and the human HSPA2 gene ([27]; GenBank ${ }^{\circledR}$ accession number L26336) (for details see Figure 7). Above are indicated restriction sites used for constructing hybrid genes [shown in (B)] for functional studies. N1, Dd, I, Bs, RV, B, Dr, RI, H stand for EcoNI, DrdI, Hincll, BstXI, EcoRV, BamHI, Drall, EcoRI and HindlII restriction enzymes respectively. (B) Summary of the data from the transgenic mice analysis (top part) and the transient transfection assays (bottom part). Lines represent DNA fragments linked to a reporter gene. Open rectangles represent reporter genes; numbers within ascribe each construct arbitrarily. Activity of constructs 1 and 2 were assayed in [15]. Activity of constructs 3 , 4, 5 and 7 were assayed in [14]. Activity of constructs 3 and 7 were assayed in [19]. Activity of clones 5, 6, 7, 8, 9 and 10 were assayed in the present paper. $(+)$ and $(-)$ indicate the activity or inactivity of a given construct respectively.

do not seem to be alternative sites that could function in a tissue-specific manner. As has been shown previously, the Hst70/Hsp70.2 gene transcripts are also present, besides the testes, in several somatic tissues, predominantly in the brain $[9,10]$. However, we found that the $H s t 70$ gene transcripts in the brain are initiated both from the T2 region [14] and from the T1 region (D. Ścieglińska, unpublished work). We cannot exclude the possibility that the presence of different $5^{\prime}$ UTR sequences may have some regulatory functions.

The presence of two distant transcription initiation regions, with one located within an intron, raises questions about the localization of DNA regulatory sequences responsible for high testis-specific expression of the Hst70 and Hsp70.2 genes. At present, the position of the 'cis' regulatory elements can only be a matter of speculation. Figure 6 summarizes the data from functional analysis of the $H s t 70$ and $H s p 70.2$ gene promoters in transgenic mice and in vitro transient transfections performed previously $[14,15,19]$ and during the present study. First, it is obvious that the DNA sequences localized between the T2 transcription initiation region and the ATG codon are not important for testis-specific expression of transgenes. Secondly, the shortest promoter fragment able to maintain transcriptional activity of transgenes was found to be $367 \mathrm{bp}$ long and localized upstream of the translation start region [14]. The 5' end of this fragment is thus localized approx. $20 \mathrm{bp}$ upstream of the T1 region and $252 \mathrm{bp}$ upstream of the $\mathrm{T} 2$ region. Cutting off $42 \mathrm{bp}$ from the $5^{\prime}$ end of this fragment [pHST(326/D)CAT transgene] results in reduction of its expression in transgenic mice to almost background levels. This suggests the DNA sequences responsible for testis-specific expression would be localized within exon 1 and the intronic sequences.

The above concept is supported by computer-assisted searches for the possible regulatory sequences localized between the T1 and $\mathrm{T} 2$ regions and upstream of the $\mathrm{T} 1$ region. The analysis 


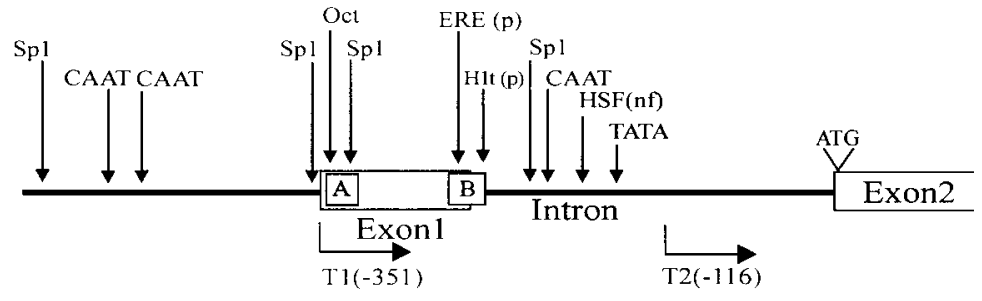

Box A

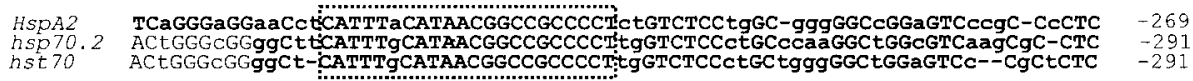

Box B

HsPA2 GtCCAaCT tGAaATCtGTTGGgtCACgGGCCaUGTACTCCGACCEAGGCAAGCCTGTGG

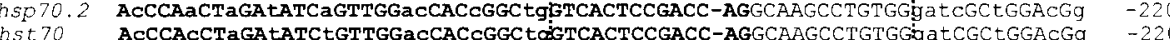
hst 70

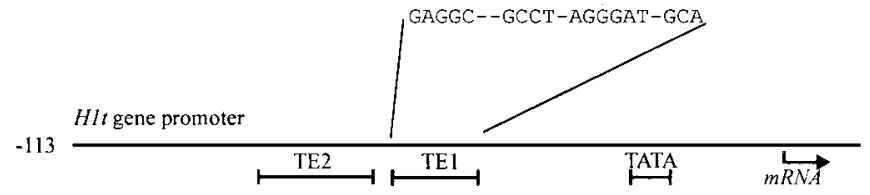

\section{Figure 7 Possible regulatory elements localized upstream of the ATG codon of the Hst70 gene}

The top part of the Figure shows the structure of the $5^{\prime}$ region of the Hst70 gene with the indicated position of recognition sequences for several transcription factors. Heat shock element-like and oestrogen response element (ERE)-like elements were found to be non-functional [5,19]. Functional studies with other elements have not yet been performed. The bottom part of the Figure shows the alignment of DNA sequences localized upstream of the T2 transcription region of the rat Hst70 gene with the corresponding region of the mouse Hsp70.2 gene and the human HSPA2 gene. The most conserved regions are boxed (boxes A and B). Capital letters indicate perfectly matched nucleotides, small-case letters indicate mismatched nucleotides, and letters not in bold type indicate nucleotides absent from mature mRNA transcripts. Within box B a short sequence with a significant similarity to part of the promoter of testis-specific histone H1t variant was identified. TE1 and TE2 are subfragments of the TE region, which seems to be essential for testis-specific expression of the H1t gene [25,28]. HSF, heat shock factor; nf, non-functional; Oct, octamer; $p$, putative.

shows that between the regions T1 and T2 there are several DNA motifs, such as a TATA box, a CAAT box, three $\mathrm{Sp} 1$ boxes, heat shock element-like and oestrogen response element-like elements and the octamer box, all of which are possible sites of interaction with general transcription factors. The alignments of the rat Hst70 gene and its mouse and human homologues revealed two short, almost perfectly conserved, regions which we called A and B boxes (see Figure 7). The A box contains the Sp1 and octamer regions, while the $\mathrm{B}$ box sequences of the $H s t 70$ gene show strong similarity to the 'cis' acting element which binds a testis-specific factor in the promoter of the testis-specific variant of the histone $\mathrm{H} 1$ [25]. This is in fact the only region of such strong similarity within promoters of genes expressed in spermatocytes identified so far. However, whether this element is involved in the regulation of Hst70 gene activity remains unknown.

Interestingly, beside two CAAT boxes and one $\mathrm{Sp} 1$ region, neither sequences resembling recognition regions for known transcription factors nor sequences similar to potential regulatory elements in other spermatocyte- or spermatid-specific genes could be found within the promoter fragment upstream of the T1 region [26]. Nevertheless, the sequences localized upstream of the $\mathrm{T} 1$ region posses general promoting potential demonstrated in transfection experiments using 3 '-end truncated fragments of the Hst70 gene promoter region (Figure 5).

In summary, the present study together with data presented previously $[5,10,14,15,19]$ demonstrates that the promoter structure of the rat Hst70 gene and of its mouse counterpart, the Hsp70.2 gene, are similar and rather complex. Transcription of both genes can be initiated in two main distant regions, as well as in several minor sites localized around the main ones. Although the DNA sequences localized upstream of the distal $\mathrm{T} 1$ region are able to promote transcription, it seems that most ' $c i s$ ' elements important for gene promoter activity and its testisspecific usage are localized within the first, non-coding, exon and within an intron. We trust that the present work provides a solid base for further investigations using transgenic mice and band shift assays. Their aim will be to attempt precise determination of 'cis' and 'trans' regulatory elements conferring the testis-specific expression of the Hst70 and Hsp70.2 genes.

We thank Mrs K. Klyszcz for skillful technical assistance. This work has been mainly supported by a grant from the State Committee for Scientific Research (grant 6 P04 A 037 15; to Z.K.), by a short-term fellowship from the Centre of International Mobility, Finland (to D. S. and W. K.) and a grant from the Academy of Finland (to I.H.).

\section{REFERENCES}

1 Matsumoto, M. and Fujimoto, H. (1990) Cloning of a hsp70-related gene expressed in mouse spermatids. Biochem. Biophys. Res. Commun. 166, 43-49

2 Zakeri, Z. F. and Wolgemuth, D. J. (1987) Developmental-stage-specific expression of the hsp70 gene family during differentiation of the mammalian male germ line. Mol. Cell. Biol. 7, 1791-1796

3 Walter, L., Rauch, F. and Günther, E. (1994) Comparative analysis of the three major histocompatibility complex-linked heat shock protein 70 (Hsp70) genes of the rat. Immunogenetics 40, 325-330

4 Krawczyk, Z., Wiśniewski, J. and Biesiada, E. (1987) A hsp70-related gene is constitutively and highly expressed in testis of rat and mouse. Mol. Biol. Rep. 12 27-34

5 Wiśniewski, J., Kordula, T. and Krawczyk, Z. (1990) Isolation and nucleotide sequence analysis of the rat testis-specific major heat-shock (HSP70)-related gene. Biochim. Biophys. Acta 1048, 93-99

6 Zakeri, Z. F., Wolgemuth, D. J. and Hunt, C. R. (1988) Identification and sequence analysis of a new member of the mouse HSP70 gene family and characterization of its unique cellular and developmental pattern of expression in the male germ line. Mol. Cell. Biol. 8, 2925-2932 
7 Krawczyk, Z., Szymik, N. and Wiśniewski, J. (1987) Expression of hsp70-related gene in developing and degenerating rat testis. Mol. Biol. Rep. 12, 35-41

8 Krawczyk, Z., Mali, P. and Parvinen, M. (1988) Expression of a testis-specific hsp70 gene-related RNA in defined stages of rat seminiferous epithelium. J. Cell Biol. 107, $1317-1328$

9 Murashov, A. I. and Wolgemuth, D. J. (1996) Distinct transcripts are recognized by sense and antisense riboprobes for a member of the murine HSP70 gene family, HSP70.2, in various reproductive tissues. Mol. Reprod. Dev. 43, 17-24

10 Ścieglińska, D., Widłak, W., Rusin, M., Markkula, M. and Krawczyk, Z. (1997) Expression of the testis-specific hsp70-related gene (hst70 gene) in somatic nontesticular rat tissues revealed by RT-PCR and transgenic mice analysis. Cell Biol. Int 21, 813-821

11 Dix, D. J., Allen, J. W., Collins, B. W., Mori, C., Nakamura, N., Poorman-Allen, P., Goulding, E. H. and Eddy, E. M. (1996) Targeted gene disruption of hsp70-2 results in failed meiosis, germ cell apoptosis and male infertility. Proc. Natl. Acad. Sci. U.S.A. 16, 3264-3268

12 Dix, D. J., Allen, J. W., Collins, B. W., Poorman-Allen, P., Mori, C., Blizard, D. R., Brown, P. R., Goulding, E. H., Strong, B. D. and Eddy, E. M. (1997) HSP70-2 is required for desynapsis of synaptonemal complexes during meiotic prophase in juvenile and adult mouse spermatocytes. Development (Cambridge, U.K.) 124, 4595-4603

13 Zhu, D., Dix, D. J. and Eddy, E. M. (1997) HSP70-2 is required for CDC2 kinase activity in meiosis I of mouse spermatocytes. Development (Cambridge, U.K.) 124, 3007-3014

14 Widłak, W., Markkula, M., Krawczyk, Z., Kananen, K. and Huhtaniemi, I. (1995) A 252 bp upstream region of the rat spermatocyte-specific hst70 gene is sufficient to promote expression of the hst70-CAT hybrid gene in testis and brain of transgenic mice. Biochim. Biophys. Acta 1264, 191-200

15 Dix, D. J., Rosario-Herrle, M., Gotoh, H., Mori, C., Goulding, E. H., Barret, C. V. and Eddy, E. M. (1996) Developmentally regulated expression of Hsp70-2 and Hsp702/lacZ transgene during spermatogenesis. Dev. Biol. 174, 310-321

16 Chomczyński, P. and Sacchi, N. (1987) Single-step method of RNA isolation by acid guanidinium isothiocyanate-phenol-chloroform extraction. Anal. Biochem. 162 156-159

Received 20 March 2001/14 June 2001; accepted 26 July 2001
17 Sambrook, J., Fritsch, E. F. and Maniatis, T. (1989) Molecular Cloning: A Laboratory Manual, 2nd edn., Cold Spring Harbor Laboratory Press, Cold Spring Harbor, NY

18 Hogan, B. L., Costantini, F. and Lacy, E. (1986) Manipulating the Mouse Embryo: A Laboratory Manual, Cold Spring Harbor Labortory Press, Cold Spring Harbor, NY

19 Krawczyk, Z., Schmid, W., Harkonen, P. and Wolniczek, P. (1993) The ERE-like sequence from the promoter region of the testis specific hsp70-related gene is not estrogen responsive. Cell Biol. Int. 17, 245-253

20 Pothier, P., Quellet, M., Julien, J.-P. and Guerin, S. L. (1992) An improved CAT assay for promoter analysis in either transgenic mice or tissue culture cells. DNA Cell Biol. 11, 83-90

21 Bradford, M. M. (1976) A rapid and sensitive method for quantitation of microgram quantities of protein utilizing the principle of protein-dye binding. Anal. Biochem. 72 248-254

22 Datta, U., Wexler, I. D., Kerr, D. S., Raz, I. and Patel, M. S. (1999) Characterization of the regulatory region of the human testis-specific form of the pyruvate dehydrogenase $\alpha$-subunit (PDHA-2) gene. Biochim. Biophys. Acta 1447, 236-243

23 Wolfe, S. A. and Grimes, S. R. (1999) Binding of nuclear proteins to an upstream element involved in transcriptional regulation of the testis-specific histone $\mathrm{H} 1 \mathrm{t}$ gene. J. Cell. Biochem. 75, 555-565

24 Wiśniewski, J., Maleszewski, M., Krawczyk, Z. and Gedamu, L. (1993) An upstream region of the rat spermatogenesis-specific heat-shock-like hst70 gene confers testisspecific expression in transgenic mice. Eur. J. Biochem. 212, 137-143

25 Grimes, S. R., Wolfe, S. A. and Koppel, D. A. (1992) Temporal correlation between the appearance of testis-specific DNA-binding proteins and the onset of transcription of the testis-specific histone H1t gene. Exp. Cell Res. 201, 216-224

26 Lele, K. and Wolgemuth, D. (1998) The role of transcriptional control during spermatogenesis. J. Androl. 19, 639-649

27 Bonnycastle, L. L. C., Yu, C.-E., Hunt, C. R., Trask, B. J., Clancy, K. P., Weber, J. L., Patterson, D. and Schenberg, G. D. (1994) Cloning, sequencing, and mapping of the human chromosome 14 heat shock protein gene (HspA2). Genomics 23, 85-93

28 Van Wert, J. M., Panek, H. R., Wolfe, S. A. and Grimes, S. R. (1998) The TE promoter element of the histone $\mathrm{H} 1 \mathrm{t}$ gene is essential for transcription in transgenic mouse primary spermatocytes. Biol. Reprod. 59, 704-710 